\title{
Reduction of Porous Media Permeability from In Situ Leuconostoc mesenteroides Growth and Dextran Production
}

\author{
Raymond E. Lappan* and H. Scott Fogler ${ }^{\dagger}$ \\ Department of Chemical Engineering, The University of Michigan, Ann \\ Arbor, Michigan 48109-2136; e-mail:sfogler@engin.umich.edu
}

Received June 6, 1995/Accepted October 4, 1995

In situ growth of bacteria in a porous medium can alter the permeability of that media. This article reveals that the rate of permeability alteration can be controlled by the inoculation strategy, nutrient concentrations, and injection rates. Based on experimental observations a phenomenological model has been developed to describe the inoculation of the porous medium, the in situ growth of bacteria, and the permeability decline of the porous medium. This model consists of two phases that describe the bacteria in the porous medium: (1) the nongrowth phase in which cell transport and retention are occurring; and (2) the growth phase in which the retained cells grow and plug the porous media. Transition from the transport phase to the growth phase is governed by the growth lag time of the cells within the porous medium. The importance of the inoculum injection strategy and the nutrient injection strategy is illustrated by the model. (c) 1996 John Wiley \& Sons, Inc.

Key words: Leuconostoc mesenteroides - transport • growth model, in situ - bacterial profile modification

\section{INTRODUCTION}

A technique often used by the oil industry to enhance oil production is to introduce water into the reservoir through a series of injection wells. The injected water displaces the oil in the reservoir which is transported to recovery wells. This technique, which is called water flooding or secondary oil recovery, aids in recovering up to $70 \%$ of the oil in the reservoir. ${ }^{19}$ Failure to recover all of the interstitial oil during water flooding can be attributed to permeability heterogeneity of the reservoir. High permeability zones in the reservoir facilitate the transport of a large fraction of the injected water to create "water fingers" that result in a majority of the interstitial oil being bypassed. A common practice in rectifying this problem is to selectively plug these waterswept zones by injection of reagents that will enable water injection to be resumed in the oil-rich zones.

In a previous study we showed the technical feasibility of using Leuconostoc mesenteroides for the plugging of these high permeability zones. This process has been termed by the authors as bacterial profile modification (BPM). ${ }^{9}$ The application of such a technique requires

\footnotetext{
* Currently at McMaster University, Hamilton, Ontario.

$\dagger$ To whom all correspondence should be addressed.
}

a thorough understanding of reservoir conditions, bacterial growth kinetics, and both bacteria and nutrient transport within porous media. In addition, bacterial profile modification is also finding applications in ground-water flows and in in situ bioremediation. Here, the biofences, which are a contained zone produced by BPM, are being studied to elucidate their effectiveness to contain and degrade contaminate spills (NAPLS; e.g., nonaqueous phase liquids)

The successful application of bacteria for fluid control is highly dependent on the reservoir's environmental conditions, such as $\mathrm{pH}$, salinity, temperature, pressure, and permeability. ${ }^{2}$ If a reservoir is environmentally suitable for bacterial growth, the only control in the implementation of the BPM technique is through controlled bacterial placement and in situ growth (i.e., injection strategy). This article discusses the effect of nutrient injection rates and nutrient concentrations on in situ growth of $L$. mesenteroides in porous media and the resulting permeability decline. This study was accomplished through a series of experiments involving parallel-core plugging, flow rate (Damköhler) effects, and parameter estimation experiments.

\section{MATERIALS AND METHODS}

Experiments were carried out to determine how in situ cell and exopolysaccharide production influences the permeability of porous media. These experiments consisted of two phases: (1) the initial injection of bacteria into the porous medium; and (2) the subsequent injection of a nutrient feed into the porous medium to promote cell growth and exopolymer production. The experimental procedures for bacteria and nutrient injection are similar to those previously discussed by the authors. ${ }^{9}, 11$ The only exceptions were the inoculum preparation for the Damköhler (i.e., flow rate) experiments and for the first set of parallel-core plugging experiments (PCE-I). The inoculant cells for these experiments were grown in standard medium, but were then removed by centrifuging (at $4480 \mathrm{~g}$ for $5 \mathrm{~min}$ ) and resuspended in new growth media before injection. ${ }^{9}$ This additional step prevents waste products from being injected. The specifics of the inoculum growth media, the 
nutrient feed composition, and the location of the pressure taps for the series of three experiments are presented in Table I. Effluent samples for the parameter estimation experiments were collected and analyzed to determine cell and sucrose concentrations using the procedures outlined previously by the authors. ${ }^{9}$

\section{Theory}

A continuum approach can be used to model the growth and transport of L. mesenteroides in porous media. Because the experiments were carried out in linear porous ceramic cores, we shall only consider transport in one dimension. The mass balances on the bacteria cells and on the species in solution are given by Eqs. (1) and (2).

Balances of surface bound species (including sessile cells):

$$
\varepsilon \frac{\partial \sigma_{i}}{\partial t}=\varepsilon r_{i \text { generation }}-\varepsilon \sum r_{i \text { transport }}
$$

Balance on species in solution (including planktonic cells): $\varepsilon \frac{\partial C_{i}}{\partial t}+U_{s} \frac{\partial C_{i}}{\partial z}=D_{i} \frac{\partial^{2} C_{i}}{\partial z^{2}}+\varepsilon r_{i \text { generation }}$

$$
+\varepsilon \sum r_{i \text { transport }}
$$

Because variations in porosity are small, the pseudosteady-state porosity condition is used in modeling the transport of the various species. Under these conditions, the porosity was calculated from the following equation:

$$
\varepsilon=\varepsilon^{\circ}\left(1-\Sigma \sigma_{i} / \rho_{i}\right)
$$

\section{Permeability Reduction}

The change in local permeability for a differential volume of a porous medium is dependent on the change in local porosity. Models for relating permeability and porosity have been developed for biofilm growth in unconsolidated porous media (sand packs). ${ }^{16}$ For consolidated porous media, the local permeability at any time $t$ and location $z$ is given by the equation:

$$
\frac{k_{\text {loc }}}{K_{0}}=\mathrm{e}^{(\beta \Delta \varepsilon)}
$$

\begin{tabular}{|c|c|c|c|c|}
\hline & \multirow[b]{2}{*}{ Damköhler } & \multicolumn{2}{|c|}{ Parallel } & \multirow[b]{2}{*}{ Parameter estimation } \\
\hline & & PCE-I & PCE-II & \\
\hline \multicolumn{5}{|l|}{ Inoculum } \\
\hline Initial growth media & $\begin{array}{l}10 \mathrm{~g} \mathrm{YE} / \mathrm{L}, \\
7.9 \mathrm{~g} \text { glucose } / \mathrm{L}, \\
7.9 \mathrm{~g} \text { fructose } / \mathrm{L}\end{array}$ & $\begin{array}{l}10 \mathrm{~g} \mathrm{YE} / \mathrm{L}, \\
7.9 \mathrm{~g} \text { glucose } / \mathrm{L}, \\
7.9 \mathrm{~g} \text { fructose } / \mathrm{L}\end{array}$ & $\begin{array}{l}10 \mathrm{~g} \mathrm{YE} / \mathrm{L} \\
10 \mathrm{~g} \text { glucose } / \mathrm{L} \\
10 \mathrm{~g} \text { fructose } / \mathrm{L}\end{array}$ & $\begin{array}{l}10 \mathrm{~g} \mathrm{YE} / \mathrm{L} \\
7.9 \mathrm{~g} \text { glucose } / \mathrm{L} \\
7.9 \mathrm{~g} \text { fructose } / \mathrm{L}\end{array}$ \\
\hline Resuspension ${ }^{a}$ & Yes & Yes & No & No \\
\hline $\begin{array}{l}\text { Injection rate (mL/ } \\
\text { min) }\end{array}$ & 5.0 & 5.0 & 3.0 & 1.0 \\
\hline $\begin{array}{l}\text { Injection duration } \\
\text { (min) }\end{array}$ & 60 & 60 & 20 & 60 \\
\hline $\begin{array}{l}\text { Cell concentration } \\
\quad(\text { cells } / \mathrm{L})\end{array}$ & $\sim 1 \times 10^{11}$ & $\sim 1 \times 10^{11}$ & $\sim 1 \times 10^{12}$ & $8.61 \times 10^{11}$ \\
\hline \multicolumn{5}{|l|}{ Core } \\
\hline Diameter $(\mathrm{cm})$ & 2.54 & 2.54 & 2.54 & 2.58 \\
\hline Length(s) $(\mathrm{cm})$ & 5.1 & $\mathrm{HP}=6.25, \mathrm{LP}=6.30$ & $\mathrm{HP}=7.65, \mathrm{LP}=7.75$ & 7.9 \\
\hline Permeability(ies) (mD) & 11,000 & $\mathrm{HP}=13,000, \mathrm{LP}=66$ & $\mathrm{HP}=3800, \mathrm{LP}=16$ & 11,800 \\
\hline $\begin{array}{l}\text { Core saturation } \\
\text { composition }\end{array}$ & Same as feed & Same as feed & $10 \mathrm{~g} \mathrm{YE} / \mathrm{L}$ & Same as inoculum media \\
\hline \multicolumn{5}{|l|}{ Feed } \\
\hline Composition & $\begin{array}{l}\text { All } 10 \mathrm{~g} \text { YE } / \mathrm{L}, \text { sucrose; } \\
\text { DE-I }=15 \mathrm{~g} / \mathrm{L} \\
\text { DEII }=15 \mathrm{~g} / \mathrm{L} \\
\text { DE-III }=1.5 \mathrm{~g} / \mathrm{L}\end{array}$ & $\begin{array}{l}10 \mathrm{~g} \mathrm{YE} / \mathrm{L}, \\
15 \mathrm{~g} \text { sucrose } / \mathrm{L}\end{array}$ & $\begin{array}{l}10 \mathrm{~g} \mathrm{YE} / \mathrm{L} \\
18 \mathrm{~g} \mathrm{sucrose} / \mathrm{L}\end{array}$ & $\begin{array}{l}10 \mathrm{~g} \mathrm{YE} / \mathrm{L} \\
20 \mathrm{~g} \text { sucrose } / \mathrm{L}\end{array}$ \\
\hline $\begin{array}{l}\text { Injection rate } \\
(\mathrm{mL} / \mathrm{min})\end{array}$ & $\begin{array}{l}\text { DE-I }=0.1 \\
\text { DE-II }=1.0 \\
\text { DE-III }=1.0\end{array}$ & 0.2 & 0.2 & 1.0 \\
\hline $\begin{array}{l}\text { Pressure tap locations } \\
\text { from injection face }\end{array}$ & $\begin{array}{l}\text { Inlet, } 12 \mathrm{~mm} \\
\quad 38 \mathrm{~mm}\end{array}$ & $\begin{array}{l}\text { Inlet, } \\
25.4 \mathrm{~mm} \\
\text { (for each core) }\end{array}$ & $\begin{array}{l}\text { Inlet, } 38 \mathrm{~mm} \text { (for } \\
\text { each core) }\end{array}$ & $\begin{array}{l}\text { Inlet, } 6.4 \mathrm{~mm} \\
32 \mathrm{~mm}\end{array}$ \\
\hline
\end{tabular}

Table I. Experimental material characteristic and procedures.

$\mathrm{YE}=$ yeast extract $($ Difco) $\mathrm{HP}=$ high permeabiltiy core; $\mathrm{LP}=$ low premeability core.

a Centrifuged at $4400 \mathrm{~g}$ and suspended in a $\sim 500 \mathrm{~mL}$ of feed solution. 
Eq. (4) is used to determine the overall permeability of the porous media, $K$, by integrating the local permeability over the entire length of the core $(\mathrm{L})$; that is ${ }^{12}$ :

$$
\frac{K}{K_{0}}=\frac{L}{\int_{0}^{\mathrm{L}} \frac{k_{0}}{k_{\mathrm{loc}}} d z} .
$$

\section{RESULTS AND DISCUSSION}

Three types of experiments were undertaken: parallelcore plugging experiments; Damköhler experiments; and parameter estimation experiments. These experiments describe different facets of bacteria transport in porous media. The core plugging experiments demonstrate how bacteria can divert flow from one zone (e.g., a high permeability) to another. The Damköhler experiments demonstrate the conditions for which plugging of porous media will occur. The final set is used to determine the model parameters used to describe flow, transport, and plugging of porous media by bacteria.

\section{Parallel-Core Flood Experiments}

In these experiments, nutrient and bacteria were injected simultaneously through two parallel cores. Figure 1 shows the ratio of the flow rate through the low permeability, $Q_{i}$, to that through the high permeability core, $Q_{h}$, as a function of time. The large differences in the permeability of the cores resulted in $99 \%$ of the fluid initially flowing through the high permeability cores, emulating a water-swept zone within a reservoir. The injection of cells did not cause any initial measurable damage to the core system or to the distribution of flows to the cores.

For the first hour of nutrient injection, no plugging was observed for either of the parallel-core plugging experiments. With time, however, the high permeability cores began to plug, which resulted in the diversion of

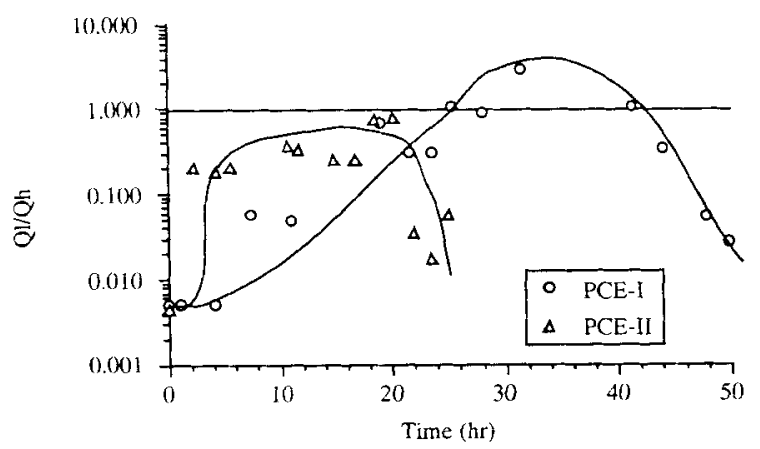

Figure 1. Low permeability to high-permeability flow ratio for parallel-core experiments PCE-I and PCE-II. nutrient feed from the high permeability cores to the low permeability cores, as shown in Figure 1. This diversion was the result of biomass generation which blocked the pore space in the high permeability cores. Results further demonstrate that both Parallel Core Experiments, PCE-I and PCE-II (see Fig. 1), exhibited a maximum diversion of flow to the low permeability core. For PCE-I a maximum flow diversion ratio of 1.3 was reached in $30 \mathrm{~h}$, while PCE-II reached a maximum of 0.8 after $18 \mathrm{~h}$ of nutrient injection. The occurrence of these respective maximums, and the eventual degeneration of the low permeability cores is the result of cell growth which blocked the pores in the low permeability cores.

The difference in the time required to reach the maximum flow diversion is believed to be the result of differences in the way the bacterial plugs developed in the high permeability cores. By standard bacterial staining techniques it was observed that both low permeability cores exhibited damage only near the injection face. Sakar et al. also observed similar plugging near the core face. ${ }^{13}$ However, both high permeability cores demonstrated plugging deep within the cores, although the depth of the plug in the high permeability cores varied. The high permeability core used in PCE-I had a bacterial plug depth of $4.4 \mathrm{~cm}$, while the high permeability core from PCE-II demonstrated only a plug depth of $1.3 \mathrm{~cm}$. The difference in the plug depth development is the result of the differences in the inoculum size and concentration, the permeability of the cores, and the growth media used to saturate the cores.

It is known that cell concentration plays a significant role in the depth of penetration of cells into a porous medium; the lower the cell concentration the greater the depth of penetration of cells into the medium. ${ }^{6}$ In addition, the permeability, which can be related to the pore size, will affect the initial placement of cells in the core and their movement in a porous medium. The higher the core permeability, the larger the mean pore size for the media. Because the permeability of the high permeability core in experiment PCE-I was greater than that of PCE-II and the inoculum concentration was lower, the depth of the penetration of cells into the core was expected to be greater for PCE-I, resulting in the development of bacteria plugs deeper in the core. In addition, the saturation and suspension solutions used in PCE-I contained sucrose which influences the initiation of cell growth and polymer production within the cores and thus the location of the plug.

These experiments support the idea that microorganisms can be used for profile modification. However, the design and control of when and where plugging occurs within the reservoir proves to be difficult. Consequently, there is need for the development of an in situ growth model to elucidate an injection strategy for the exploitation of this plugging phenomena. 


\section{Damköhler Experiments}

The next series of experiments are referred to as Damköhler experiments (DE). Damköhler experiments study the effect of the ratio of the rate of nutrient consumption to the rate of nutrient transport on bacterial transport and plugging of the cores. Table II lists the feed conditions and the time lag before apparent damage for the Damköhler experiments. Figure 2a-c show the increased pressures in the cores as a function of time. The cells' growth rate (in situ) is influenced by both time and flow rate.

A number of interesting effects were observed in these experiments, the first being the time required by the cells to damage the porous medium (i.e., reduce permeability). Experiment DE-I had a high sucrose concentration $(15 \mathrm{~g} / \mathrm{L})$ injected at a slow rate of $0.1 \mathrm{~mL} / \mathrm{min}$. The time necessary to damage this core was long, requiring over $69 \mathrm{~h}$. The feed for DE-II contained the same sucrose concentration as DE-I, however, the feed injection rate was tenfold greater at $1.0 \mathrm{~mL} / \mathrm{min}$. Experiment DE-II shows damage to the porous medium occurred immediately. Thus, it can be concluded that the transport of nutrient to the bacteria within the core significantly affects the rate at which the cores plug.

The effects of the nutrient concentration, and hence the rate of polymer production, on core plugging are also shown to influence the time required by the cells to damage the media. DE-III (Figure 2c) showed no measurable damage during the 96 hour experiment. The sucrose concentration of the feed used for DE-III was one tenth of the concentration of DE-II (i.e., $1.5 \mathrm{~g} / \mathrm{L}$ ), while the feed injection rate was the same as for DEII. Considering the fact that the feed injection rates were the same for each experiment, it can be concluded that it was the nutrient concentration that influenced the rate of plugging. The only other possible explanation could be that an insufficient quantity of cells were present in the core during the DE-III experiment. To demonstrate that viable cells were still present within the core, a second feed solution containing $15 \mathrm{~g} / \mathrm{L}$ of sucrose was injected at a rate of $0.5 \mathrm{~mL} / \mathrm{min}$. Within $1 \mathrm{~h}$ after the injection of this feed, the core began to plug, demonstrating that the cells were present within the core, but

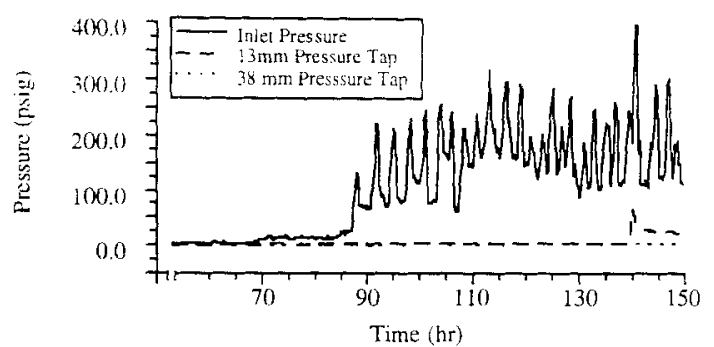

(a)

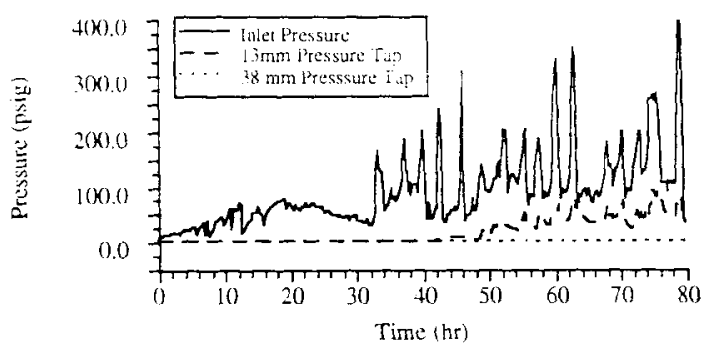

(b)

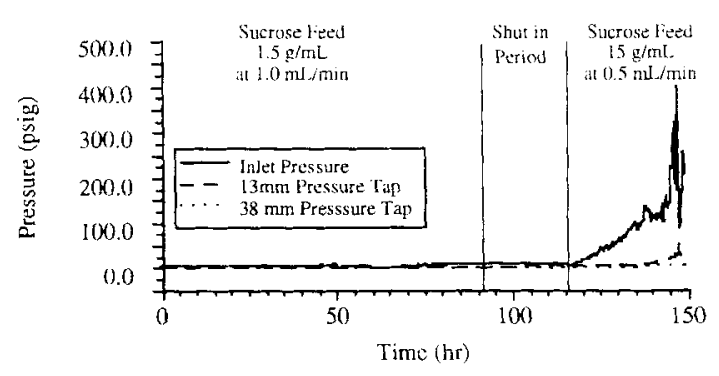

(c)

Figure 2. Pressure drop across consolidated cores for different injection conditions. (a) DE-I $15 \mathrm{~g}$ sucrose $/ \mathrm{L}$ at $0.1 \mathrm{~mL} / \mathrm{min}$. (b) $\mathrm{DE}-\mathrm{I}$ $15 \mathrm{~g} \mathrm{sucrose} / \mathrm{L}$ at $1.0 \mathrm{~mL} / \mathrm{min}$. (c) DE-III 1.5 sucrose $/ \mathrm{L}$ at $1.0 \mathrm{~mL} / \mathrm{min}$.

did not receive sufficient nutrient to produce the amount of biopolymer and cells required to plug the core.

Both these effects, the reduction of damage at the low feed rates and the lack of damage at low sucrose feed concentrations, indicate that damage to porous media is dependent on the Damköhler number (i.e., the ratio of nutrient consumption to nutrient transport). However, other effects, such as the lag in cell growth, may also contribute to the variation in elapsed time before the plugging of the media begins. For these reasons, both

Table II. List of Damköhler experiments and respective lag periods before measurable permeability damage.

\begin{tabular}{lcccc}
\hline Run & $\begin{array}{c}\text { Sucrose } \\
\text { concentration }(\mathrm{g} / \mathrm{L})\end{array}$ & $\begin{array}{c}\text { Feed injection } \\
(\mathrm{mL} / \mathrm{min})\end{array}$ & $\begin{array}{c}\text { Lag time before } \\
\text { plugging }(\mathrm{h})\end{array}$ & $\begin{array}{c}\text { Lag time/ } \\
\text { space time }\end{array}$ \\
\hline DE-I & 15 & 0.1 & 69 & 29 \\
DE-II & 15 & 1.0 & Immediately & 0 \\
DE-III & 1.5 & 1.0 & $>96^{\mathrm{a}}$ & $>400$ \\
\hline
\end{tabular}

\footnotetext{
${ }^{a}$ After $96 \mathrm{~h}$ of feed injection no core damage was apparent.

${ }^{b}$ Measurable plugging translates to a minimal permeability decline, $K / K_{0}$, of 0.0013 for DE-I, and 0.014 for DE-II and DE-III.
} 
lag time and nutrient flow rate influence the rate of plugging.

A third phenomenon observed during these and other experiments was the occurrence of pressure fluctuations at the inlet and axial pressure taps after the cores began to plug. These oscillations have not been previously reported. These pressure oscillations are the result of a sequence of biomass development and biofilm sloughing. Initially, it is believed that the inoculating cells are retained mechanically in the porous media. With the constant flow of fluid and nutrients to the core, the cells begin to grow and subsequently fill the void within the core with biomass. Because the feed is injected at a constant flow rate, the inlet pressure increases due to flow constrictions resulting from the generation of biomass.

As the local permeability decreases, causing the inlet pressure to increase, a point is reached at which the injected fluid produces a local shear equal to or greater than the critical shear stress necessary for sloughing to occur. As a result the biofilm fragments slough and are transported further into the core. This concept of sloughing has been observed by Fowler et al. for biofilm growth in a radial-flow parallel-plate geometry as well as micromodel studies in our laboratory. ${ }^{5}$ These competing phenomena, plug formation and plug removal, produce the pressure fluctuations observed for these plugging experiments.

\section{Parameter Estimation Experiments}

The inlet and effluent cell, sucrose and monosaccharide concentrations in a consolidated core, along with the inlet pressure, are presented in Figures 3, 4, and 5, respectively. Again, there was no measurable damage to the porous media observed during the injection phase (see Fig. 5). In addition, the appearance of bacteria in the effluent indicates that the cells were transported through the core.

Figure 4 shows the effluent sucrose concentration data as a function of time. We see there is a period of time (ca. $10.5 \mathrm{~h}$ ) at which no appreciable change in sucrose concentration occurs. This period is followed by a sharp decline of effluent sucrose concentration until it eventu-

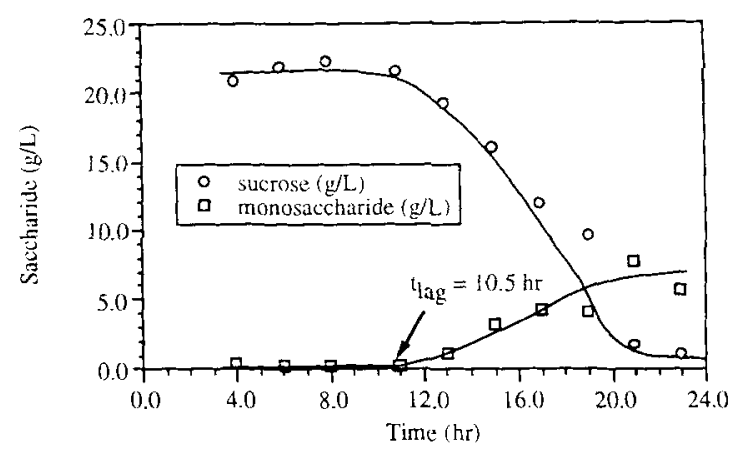

Figure 4. Effiuent sucrose and monosaccharide concentration.

ally reaches zero. Because cell maintenance is minimal, the total amount of biomass developing in the porous media (i.e., maximum cell yields) can be determined from the amount of sucrose consumed. The initial lack of sucrose consumption can be attributed to mass transfer growth limitations and/or time lag in cell growth. Mass transfer can occur by two means: (1) diffusion through the biofilm; and (2) transport into nonconducting pores. Biofilm mass transfer limitations occur when cells deep within the biofilm (multilayer) become nutrient-limited due to the diffusion rate of the nutrients from the bulk solution through the upper layers of cells and polysaccharides. Mass transfer limitations also occur when nutrients are prevented from being convectively transported to a cell within a dead pore space (nonconducting pore). Dead pores can occur naturally, that is, they can be a part of the porous medium before any bacteria are injected, or they can be created by cells that deposit in pores and thus prevent fluid (nutrient) convection.

A growth-related lag time is another possible reason that no sucrose was consumed initially. Such a phenomenon is consistent with the Dean-Hinshelwood model for lag-time prediction. ${ }^{3}$ This model correlates the lag time to the concentration of a critical intracellular constituent (i.e., no growth until the constituent reaches a critical concentration). The constituent may be a vitamin or activator that is lost from the cell into the bulk nutrient solution as the solution passes over the biofilm. In a batch system, this critical constituent remains in the bulk solution. However, a continu-

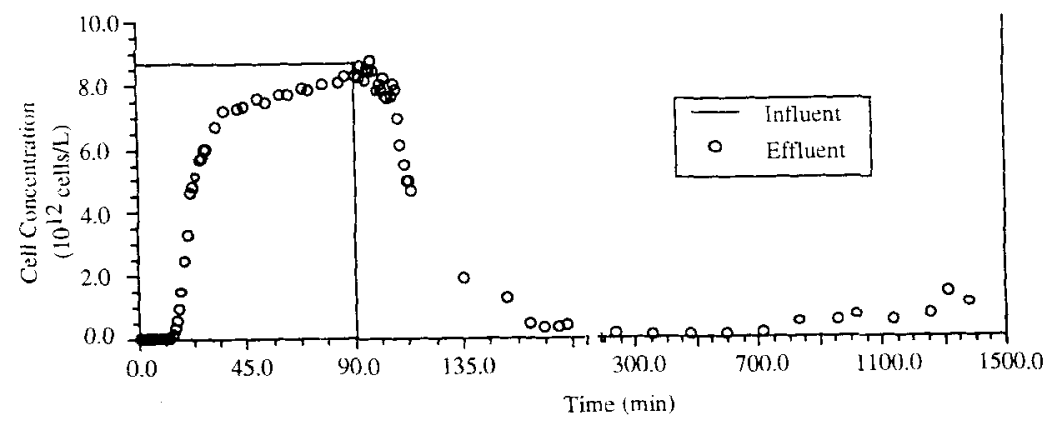

Figure 3. Influent and effluent cell concentration. 


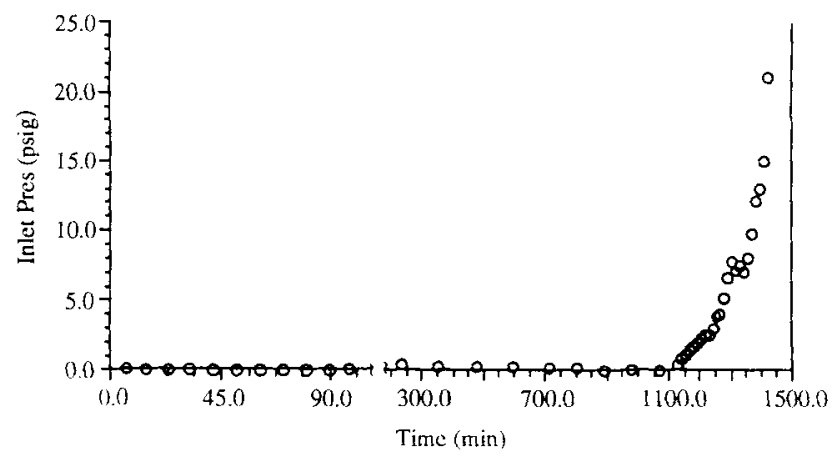

Figure 5. Resulting pressure drop through 11.8-Darcy ceramic core.

ous flow system does not allow for any bulk accumulation due to the constant flushing of the system with fresh nutrient solution.

Flushing the system would produce a lag time that is longer than the time realized during batch cultivation, which was reported to be less than $1 \mathrm{~h} .{ }^{9}$ From the data in Figure 4, a lag time of $10.5 \mathrm{~h}$ can be specified by defining the lag time as the time when a growth product appears in the effluent. For this work, the concentration of monosaccharides in the effluent has been selected as the growth product best suited for measurement and identification of the end of the lag phase.

Finally, we note that the effluent cell concentrations shown in Figure 3 exhibit an almost steady release of cells from the porous media up to the time when effluent sucrose concentrations have dropped to zero. Afterwards, an increase in the effluent cell concetration is accompanied by an increase in inlet pressure (see Fig. 5). These data suggest that, as cell growth occurs, more cells are available for release and thus account for the increase in the cell effluent concentration.

\section{MODEL DEVELOPMENT}

The model that follows has two parts: one corresponding to the inoculation period (no growth phase), and the other to the in situ growth phases of the experiment. Transition from the inoculation phase to the in situ growth phase occurs at the end of the lag time. The model parameters were estimated from the experimental data.

\section{Inoculation Phase}

During the inoculation phase the following balances on the sessile and planktonic cells are used:

$$
\begin{gathered}
\varepsilon \frac{\partial \sigma_{x}}{\partial t}=-\varepsilon \sum r_{\text {cell transport }} \\
\varepsilon \frac{\partial C_{x}}{\partial t}+U_{s} \frac{\partial C_{x}}{\partial z}=\alpha U_{s} \frac{\partial C_{x}}{\partial z^{2}}+\varepsilon \sum r_{\text {cell transport }}
\end{gathered}
$$

Eqs. (6) and (7) neglect the growth phase during inoculation. The dispersion coefficient is assumed equal to the product of the linear Darcy velocity with the dispersivity constant $\alpha$, as described by Hornberger et al. ${ }^{8}$

To complete the modeling of the inoculation, relationships for the release of sessile cells (cells deposited on interstitial surfaces) and the capture of planktonic cells (cells freely suspended) must be specified. The first order relationships, given by Hornberger et al. for the rate of deposition and entrainment, will be used and are given by the following equations $s^{7,8,17}$ :

$$
\begin{gathered}
\begin{aligned}
r_{\text {entrainment }} & =k_{1}\left(\sigma_{\mathrm{x}}-\sigma_{\mathrm{x}_{0}}\right), \\
& =0, \quad \sigma_{\mathrm{x}}>\sigma_{\mathrm{x}_{0}} \\
r_{\text {deposition }}=k_{2} C_{\mathrm{X}} & \sigma_{\mathrm{x}}<\sigma_{\mathrm{x}_{0}}
\end{aligned} \\
\text { with: } \sum r_{\text {cell transport }}=r_{\text {entrainment }}-r_{\text {deposition }}
\end{gathered}
$$

The rate of entrainment includes the term $\sigma_{x 0}$ (minimal sessile cell concentration), which accounts for cells that are irreversibly captured within the porous medium. ${ }^{17}$

Table III gives the initial and boundary conditions used to compute the values of $k_{1}, k_{2}$, and $\sigma_{x_{0}}$ in Eqs. (6)-(10). These parameter values are also presented in Table III and were determined by fitting the model to the experimental data using a least squares analysis. Minimizing the least square error was accomplished with the Simplex Method. The Method of Lines technique was used to spatially discretize ${ }^{14}$ Eqs. (6) and (7) to reduce the partial differential equations (PDEs) to a set of ordinary differential equations which were then solved with the LSODA (Livermore Solver for Ordinary Differential Equations) software package. ${ }^{10}$

Figure 6 compares the predicted results with the experimental data. Most cells within the core are sessile when cell growth begins. Consequently, the concentration of planktonic cells in the core can be neglected as an initial condition for the in situ growth model. ${ }^{10}$

\section{In Situ Growth Phase}

After the inoculation has taken place, the cells begin to grow, exopolymer begins to be produced and the core begins to plug. In our model of these processes we included mass transfer and the in situ growth lag time (growth when $t>t_{\text {lag }}$ ). The governing equations for the in situ growth model are:

$$
\begin{gathered}
\varepsilon \frac{\partial \sigma_{x}}{\partial t}=\varepsilon r_{\text {cell production }} \\
\varepsilon \frac{\partial \sigma_{e}}{\partial t}=\varepsilon r_{\text {enzyme production }} \\
\varepsilon \frac{\partial \sigma_{i d}}{\partial t}=\varepsilon r_{\text {polymer production }} \\
\varepsilon \frac{\partial C_{s i}}{\partial t}=-\varepsilon \sum r_{\text {sucrose consumption }}+\sum r_{\text {sucrose transport }} \\
\varepsilon \frac{\partial C_{s}}{\partial t}+U_{s} \frac{\partial C_{s}}{\partial z}=-\sum r_{\text {sucrose transport }}
\end{gathered}
$$

Table IV presents the boundary and initial conditions used when solving the above equations. During the in 
Table III. Inoculum model boundary and initial conditions.

\begin{tabular}{ll}
\hline (Discretization) & $30,40,50,70,120,150$ equal segments \\
$\Delta t$ (time step size) & Controlled by LSODA (erorr controlled) \\
Boundary conditions & $C_{x}$ (inlet) $=8.61 \times 10^{11}$ cell/L $\quad t<60 \mathrm{~min}$ \\
& $C_{x}($ inlet $)=0.0$ \\
& $\frac{\partial C_{x}(z=0, t)}{\partial t}=\left(C_{x}(z=0, t)-C_{x}(\right.$ inlet $\left.)\right) / \alpha$ \\
& $\frac{\partial C_{x}(z=L, t)}{\partial t}=0$ \\
& \\
Initial conditions & $C_{x}(z, t=0)=0.0$ \\
& $\sigma_{x}(z, t=0)=0.0$ \\
Final parameter values & $\alpha_{x}=0.23 \mathrm{~cm}$ \\
& $k_{1}=1.3 \times 10^{-2} \mathrm{~min}^{-1}$ \\
& $k_{2}=8.9 \times 10^{-3} \mathrm{~min}^{-1}$ \\
& $\sigma_{x 0}=5.9 \times 10^{9} \mathrm{cel}_{1} / \mathrm{L}$ \\
\hline
\end{tabular}

situ growth phase, once growth starts we assume cells within the core remain sessile due to polysaccharide production. Consequently, the cell removal rate (rate of cells becoming planktonic) is negligible relative to the cell's growth rate. We also assume the insoluble dextran and the enzyme responsible for its production remain with the cell once growth starts. Brooker has demonstrated this assumption to be quite reasonable through his micrographs of various lactic acid bacteria which showed that the dextran produced by the cells remains on the surface of the cells. ${ }^{1}$ Because the enzyme responsible for the production of dextran, dextransucrase, is typically attached to the polymer, it is justifiable to assume that the enzyme will also remain with the cell. ${ }^{4}$ Because the yeast extract is provided to the cells in excess, the model neglects any yeast extract balance.

The rate of mass transfer is proportional to the concentration differences between the bulk solution and the solution surrounding the immediate vicinity of the biofilm, and is written as:

$$
r_{\text {sucrose transport }}=k^{\prime} a\left(C_{s}-C_{s i}\right)
$$

The product, $k^{\prime} a$, combines the mass transfer coefficient, $k^{\prime}$, and the mass transfer flux area, $a$. Analysis of

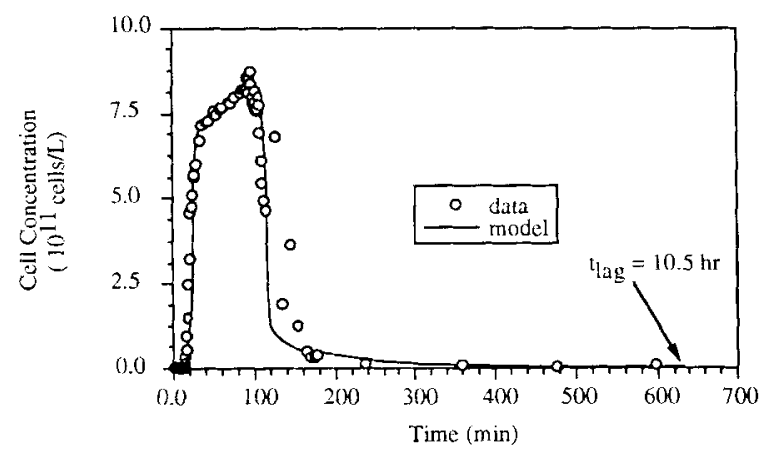

Figure 6. Inoculum model effluent planktonic cell concentration prediction. the effluent sucrose concentration data gives a mass transfer coefficient product, $k^{\prime} a$, of $12.5( \pm 1.5) \mathrm{h}^{-1}$ $\left(3.47 \times 10^{-3} \mathrm{~s}^{-1}\right)$, which is comparable to mass transfer values found by others. ${ }^{18}$ The porosity was calculated from $\mathrm{Eq}$. (3) using cell and dextran density values of $1.2 \times 10^{14} \mathrm{cells} / \mathrm{L}$ and $6.9 \times 10^{-5} \mathrm{~g}$ dextran $/ \mathrm{L} .^{10}$ The porosity-permeability correlation constant, $\beta$, of Eq. (4) was determined to be $33.8( \pm 0.2)$ using a least squares technique. Figure 7 compares the model prediction with the measured effluent surcrose concentration, while Figure 8 compares the model's permeability prediction with the experimental results.

\section{MODEL PREDICTION}

The in situ growth model describing cell growth, dextran production, and sucrose consumption requires knowledge of both the initial cell profile and the injection conditions (e.g., nutrient concentration and injection rates). Thus, manipulating the initial cell profile and the injection conditions can be used as strategies to control bacterial profile modification (BPM).

\section{Effect of Cell Concentration Profile on Core Permeability}

Three cell concentration profiles were selected to demonstrate how the initial cell distribution influences the predicted rate of plugging of the porous media. Three

Table IV. In situ model boundary and initial conditions.

\begin{tabular}{ll}
\hline (Discretization) & $30,40,50$ equal segments \\
$\Delta$ (time step size) & Controlled by LSODA (error control) \\
Boundary conditions & $C_{s}(z=0, t)=21.5 \mathrm{~g}$ sucrose $/ \mathrm{L} \quad t>t_{\text {lag }}$ \\
Initial conditions & $\sigma_{x}\left(z, t=t_{\text {lag }}\right)=$ given by inoculation model \\
& $\sigma_{e}\left(z, t=t_{\text {lag }}\right)=0.0$ \\
& $\sigma_{i d}\left(z, t=t_{\text {lag }}\right)=0.0$ \\
& $C_{s}\left(z, t=t_{\text {lag }}\right)=21.5 \mathrm{~g}$ sucrose $/ \mathrm{L}$ \\
& $C_{s i}\left(z, t=t_{\text {lag }}\right)=21.5$ g sucrose $/ \mathrm{L}$ \\
\hline
\end{tabular}




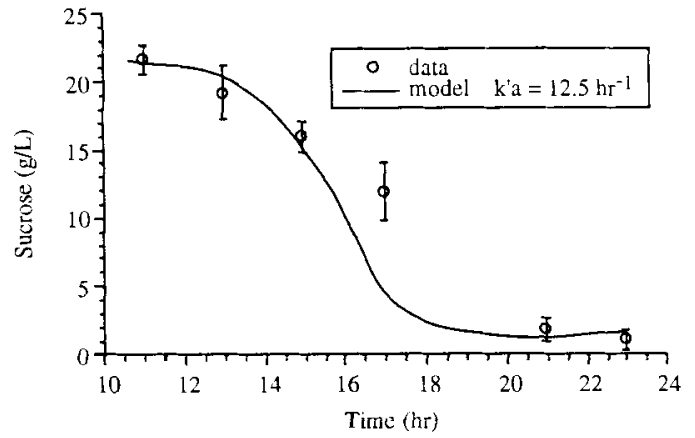

Figure 7. Model and experimental effluent sucrose concentration.

cell concentration profiles were selected to compare the effects of three extreme cell placement profiles. These profiles were cell concentrations (a) decreasing, (b) constant, and (c) increasing with distance down the core. To further strengthen the comparison between plugging rates, these initial profiles were constrained to having an equal number of deposited cells. With the additional assumption of no lag time, the in situ growth and permeability models were used to predict the resulting permeability decline resulting for each cell profile over a 15-h injection period. As can be seen from Figure 9, the most dramatic permeability reduction occurs in the core that initially had a high concentration of cells near the injection face. These results are expected because the highest cell growth and dextran production rates should occur at the injection face where the nutrient concentrations are at their maximum.

Manipulating the sessile cell profile in the subsurface is a realistic expectation and has already been studied to a limited extent. The transportability of cells, hence the resulting sessile cell profile, has been studied by Sharma et al., and was shown to be influenced by the means of cell and media surface charge-altering agents. ${ }^{15}$ Other mechanical means, such as controlling

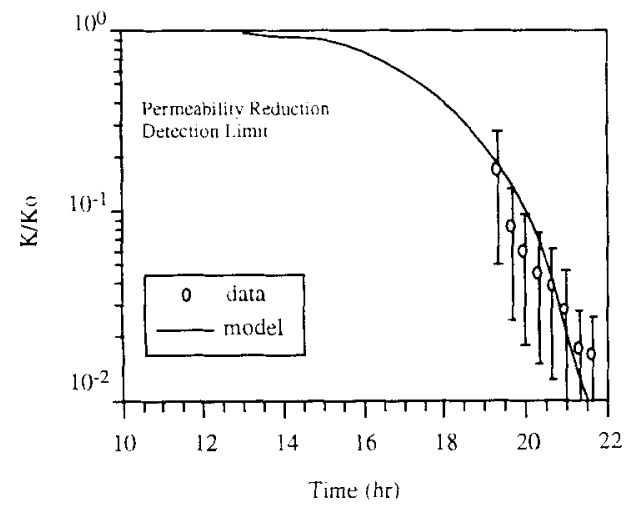

Figure 8. Predicted versus experimental permeability reduction for 3-Darcy ceramic core.

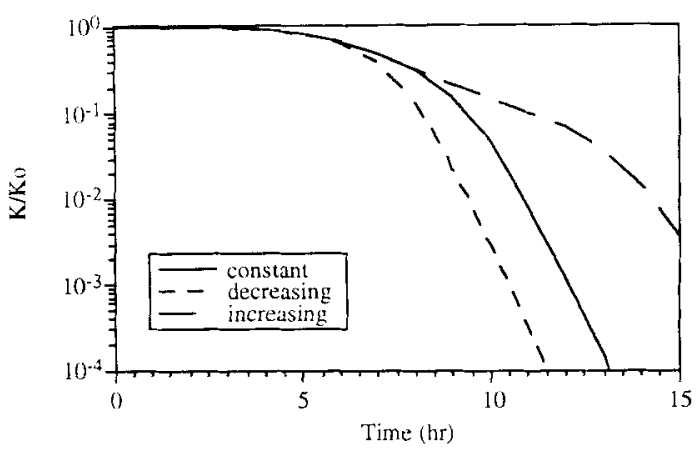

Figure 9. Effect of cell profile on core permeability (simulated Damköhler experiments at $15 \mathrm{~g}$ sucrose $/ \mathrm{L}$ at $1.0 \mathrm{~mL} / \mathrm{min}$ ).

the cell injection rate and injection concentration, have also been shown by Hart et al. to alter the cell profiles. ${ }^{6}$

\section{Effect of Injection Rate and Nutrient Concentration on Core Permeability}

Three numerical simulations were carried out to illustrate how the rate of plugging of a core can be manipulated by the nutrients injection rate and concentration. These three simulations used the same nutrient injection conditions (i.e., nutrient concentration and flow rate) as those used in the Damköhler experiments. For each of the three simulations, the cell profile was assumed to be linear and the lag time was set to zero. The results of these simulations are in Figure 10.

As seen in Figure 10, simulation SDE-III (1.5 g sucrose $/ \mathrm{L}$ at $1 \mathrm{~mL} / \mathrm{min}$ ) demonstrated no measureable plugging (damage) during the time period studied, while SDE-I (15 g sucrose/L at $0.1 \mathrm{~mL} / \mathrm{min})$ and SDE-II (15 $\mathrm{g}$ sucrose at $1 \mathrm{~mL} / \mathrm{min}$ ) both demonstrated measurable plugging. No damage was observed in simulation SDE-III because insufficient nutrients were injected to produce sufficient biomass within the time interval of the simulation. In simulations SDE-I and SDE-II suffi-

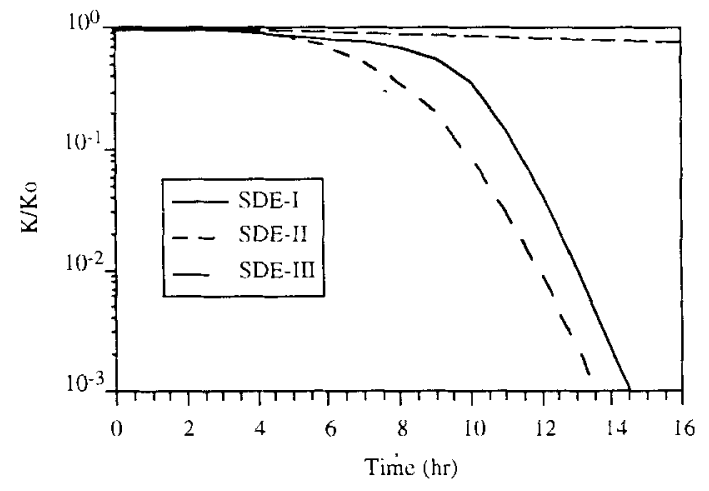

Figure 10. Effect of nutrient injection rate and nutrient concentration on core permeability. SDE-I $-15 \mathrm{~g}$ sucrose $/ \mathrm{L}$ at $0.1 \mathrm{~mL} / \mathrm{min}$; SDE-II-15 g sucrose $/ \mathrm{L}$ at $1.0 \mathrm{~mL} / \mathrm{min} ; \mathrm{SDE}-\mathrm{III}-1.5 \mathrm{~g}$ sucrose $/ \mathrm{L}$ at $1.0 \mathrm{~mL} / \mathrm{min}$ 
cient biomass was generated to damage the porous media and reduce the permeability. These results mimic the trends found during the Damköhler experiments and thus indicate that the model can be used to predict plugging rates. Matching of the model prediction to the Damköhler results, however, cannot be made because the lag time for each experiment was not known.

\section{Effect of Lag Time on Core Plugging}

Although the models are successful at predicting the effects of the cell profile and nutrient injection strategy on the rate of plugging of porous media, an estimate of the lag time is needed for field applications. This estimate is important because it specifies when the cells start to grow and thus alter the permeability of porous media. Up to now this value was determined experimentally, but further development of the model should include an equation(s) that predicts the lag time. Quantifying and modeling this lag time will result in a model that can be directly applied in the field to predict BPM.

\section{SUMMARY}

Parallel-core plugging experiments have demonstrated the feasibility of using $L$. mesenteroides for profile modification and have shown that fluid diversion is susceptible to degeneration if nutrient injection is not controlled. In addition, the ability to divert fluid has been found to be dependent upon the biomass profile that develops within the porous medium. The Damköhler experiments have shown the dependency of the plugging rate on the injection conditions such as nutrient concentration and injection rate. A continuum model that describes in situ cell growth, dextran production, and the resulting permeability decline has been developed. This model incorporates a cell growth lag time and nutrient mass transfer coefficient that control the growth of the biomass. From the model it has been shown that the initial cell profile (when cell growth commences) influences the rate of plugging, as does the concentration of the nutrients and their injection rate. Thus the proper control of initial cell placement, the nutrient injection rate, and the nutrient concentration will aid in the development of an injection strategy for BPM.

\section{NOMENCLATURE}

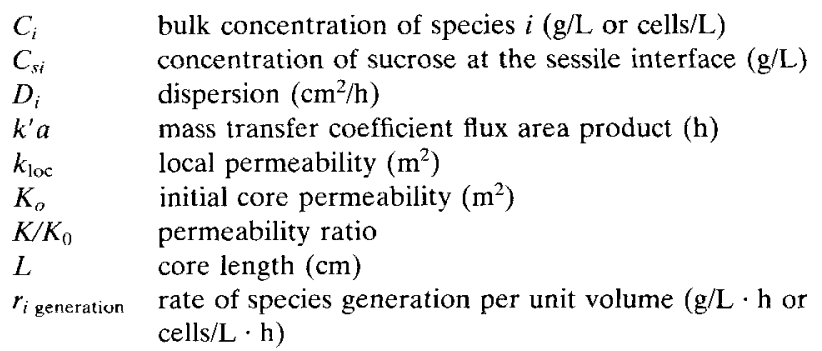

$\Sigma r_{i \text { transport }}$ sum of the rate expressions for i partitioning between surface retained and suspension states $(g / \mathrm{L} \cdot \mathrm{h})$

$t$ time $(\mathrm{h})$

$t_{\text {lag }} \quad$ in situ growth lag time (h)

$U_{s} \quad$ Darcy or superficial velocity $(\mathrm{cm} / \mathrm{h})$

$z \quad$ length dimension $(\mathrm{cm})$

Greek letters

$\begin{array}{ll}\alpha & \text { dispersivity coefficient }(\mathrm{cm}) \\ \beta & \text { proportionality constant } \\ \varepsilon & \text { porosity } \\ \varepsilon^{\circ} & \text { initial porosity } \\ \Delta \varepsilon & \text { change in local porosity } \\ \sigma_{i} & \text { concentration of surface bound species (fluid volume } \\ & \text { basis) }(\mathrm{g} / \mathrm{L}) \\ \rho_{i} & \text { density of material } i(\text { cells } / \mathrm{L} \text { or } \mathrm{g} / \mathrm{L})\end{array}$

Subscripts for kinetic parameters

$\begin{array}{ll}d & \text { soluble dextran } \\ e & \text { enzyme } \\ i & \text { index representing cells, nutrients, or polysaccharides } \\ \text { id } & \text { insoluble dextran } \\ \text { lag } & \text { lag time } \\ \text { loc } & \text { local region spatially } \\ s & \text { sucrose } \\ \text { transport } & \text { transport in fluid phase } \\ x & \text { cell } \\ 0 & \text { initial conditions }\end{array}$

\section{References}

1. Brooker, B. E. 1979. Electron microscopy of the dextrans produced by lactic acid bacteria, pp. 85-102. In R. C. W. Berkeley (ed.), Microbial polysaccharides and polysaccharases. Academic Press, New York.

2. Clark, J. B., Munnecke, D. M., Jenneman, G. E. 1981. In-situ microbial enhancement of oil production, Dev. Ind, Microbiol. 22: 695-701.

3. Dean, A. C. R., Hinshelwood, S. C. 1966. Growth, function, and regulation in bacterial cells. Clarendon Press, Oxford, UK.

4. Ebert, K. H., Schenk, G. 1968. Mechanisms of biopolymer growth: The formation of dextran and levan, pp. 179-221. In F. F. Nord (ed.), Advances in enzymology and related areas of molecular biology. International Publishers, New York.

5. Fowler, H. W., McKay, A. J. 1980. The measurement of micorbial adhesion, pp. 143-161. In R. C. W. Berkeley (ed.), Microbial adhesion to surfaces. Ellis Horwood, West Sussex, UK.

6. Hart, R. T., Fekete, T., Flock, D. L. 1960. The plugging effect of bacteria in sandstone systems. Can. Mining Met. Bull. 53:495-501.

7. Herzig, J. P., Leclerc, D. M., Le Goff, P. 1970. Flow of suspensions through porous media-application to deep filtration. Ind. Eng. Chem. 62: 8-35.

8. Hornberger, G. M., Mills, A. L., Herman, J. S. 1992. Bacterial transport in porous media: Evaluation of a model using laboratory observations. Water Resources Res. 28: 915-938.

9. Lappan, R. E., Fogler, H. S. 1994. Leuconostoc mesenteroides growth kinetics with application to bacterial profile modification. Biotechnol. Bioeng. 43: 865-873.

10. Lappan, R. E. 1994, Reduction of porous media permeability from in situ leuconostoc mesenteroides growth and polysaccharide production, Ph.D. thesis, University of Michigan, Ann Arbor, MI, USA.

11. Lappan, R. E., Fogler, H. S. 1992. Effect of bacterial polysaccharide production on formation damage. Soc. Pet. Eng. J. 7: 167-171.

12. Lund, K., Fogler, H. S. 1976. Acidization V-On the prediction 
of the movement of acid and permeability fronts in sandstone. Chem. Eng. Sci. 31: 381.

13. Sakar, A. K., Georgiou, G., Sharma, M. M., 1994. Transport of bacteria in porous media: I. An experimental investigation. Biotechnol. Bioeng. 44: 489-497.

14. Schiesser, W. E. 1991. The numerical method of lines. Academic Press, New York.

15. Sharma, M. M., Chang, Y. I., Yen T. F. 1985. Reversible and irreversible surface charge modification of bacteria for facilitating transport through porous media. Coll. Surf. 16: 193-206.
16. Taylor, S. W. and Jaffe, P. R. 1990. Biofilm growth and the related changes in the physical properties of a porous media. 1. Experimental investigation. 2. Permeability. Water Res. 26: 2153-2169.

17. Tien, C., Turian, R. M., Pandse, H. 1979. Simulation of the dynamics of deep bed filtration. AlChE J. 25: 385-395.

18. Vaidya, R. N. 1991. Fines migration and formation damage, Ph.D. thesis, University of Michigan, Ann Arbor, MI, USA.

19. Willhite, G. P. 1986. Waterflooding. Society of Petroleum Engineering, Richardson, TX. 